\title{
Studying Principle Legally and in Figh (Of His Sheep Actual Pays) Emphasis on Arising Issues
}

\author{
${ }^{*}$ Ali Asghar Moradzade \\ ${ }^{2}$ Mustafa Rajaipour
}

${ }^{1}$ Department of Jurisprudence and Law, Mashhad Branch, Islamic Azad University, Mashhad, Iran 2Department of Theology, Mashhad Branch, Islamic Azad University, Mashhad, Iran *Corresponding Author Email:f_shab2007@yahoo.com

\section{Doi:10.5901/mjss.2015.v6n2s1p656}

Abstract

The rule of "Of his sheep" means that one who benefits financially is responsible for its damage. For example, in a sale (transaction- purchase and sell) when the customer becomes owner, he is owner of its interests and benefits and thereby he will be owner of its waste in the case of financial damages. The rule is not only applied in transactions but also it is extended to all fields of jurisprudence. This paper offers a new approach of rule so that study it legally and theologically and address issues arising from legal issues.

Keywords: Trophy, Damage, Liability, Treasury and Arising issues.

\section{Introduction}

The main purpose of law is to establish order and justice. In Islamic legal system, social interest must be provided so that it makes possible to gain affective and spiritual perfection. In this respect, the legitimacy of compensation and trophy must be proven through financial and non- financial methods, therefore it is necessary to predict the binding rules so that protect material and immaterial interests of people and in the case of damage, it is compensated. It is clear that teachings related to damage determination and its examples are important as well as the answer to question of who is responsible for paying damage is also important. The context of rule is one of the patterns of determining individuals' liability.

\section{A) Semantics of rules}

In the case of expressing bases of all sciences that experts call them as "parts of sciences", the subject, principles and issues can be mentioned. Subject of science is what discusses on inherent complications and scientific issues surrounding it are proved and negated. Knowledge principles include the definitions and some testimonials that are determined before entering into any knowledge about subjects of that science. In this case, definitions with literal meaning and concepts with referent explains, that is the meaning that is referred and understood are important (Hor Ameli, 1987).

According to this logical method, recognizing rule of "Of his sheep actual pays" is dependent on recognizing its vocabularies. Rule (Qaede) means roots and bases and thereby house columns are called bases (Qavaed). Tarihi writes in "Majma Albahrein": "Rules Qaeda collection and is the foundation for what it", the colloquial meaning of rule has close relation with vocabulary meaning. Tahanoy on colloquial meaning of rule writes: "It is applicable to all kidney fractions at the disposal of its provisions thereof".

Rule is a general matter when recognizing sentences, their details coincide. Sheikh Ansari offers definition of Figh rule in Astshab (Former state credit) discussion in order to determine whether Astshab is Figh rule or a principle. He believes that Figh rule is a rule that "implementing it between Mujtahid and imitator is common and against principal rule that is special for Mujtahid" (Esfahani, 1994).

"I" is relative name, which includes male and female and any individual in any rank. "Ghonm" means trophy and benefit. "Zubaidi said: Booty and sheep annexation." and the sheep used versus pays and the damage is in the pilot said: Sheep, Agnm: hit booty in war or other."

"Ghorm" means the loss, damage, etc. It is a property that must be given to affected person when someone makes 
a financial loss to other person. The damage is applied against benefit. Financial damage includes loss of wealth or property or loss of personal interests- real or legal- due to crime such as losses or damage to a vehicle as a result of crime or loss of benefits of crime.

Moral damage is a loss that is related to honor and dignity of person or his relatives and also, it is a stroke that impairs the non- financial rights of persons due to crime and leads to mental damages of individuals. In crime, moral harm is in line with financial loss. Common sense of rule is that anyone takes advantage, he will take losses. It is not possible that one takes benefits but other takes its losses (Mesbah Yazdi, 2000).

This rule is mentioned in other terms. However, the bases of cognitive concept of this rule include two components of benefit responsibility and correlation between trophy and losses.

1. Benefit responsibility: according to this rule, an individual that benefits from a matter, he is responsible for compensation. Responsibility means a person commitment to respond for his actions and behavior towards people. The diagnostic criteria of responsibility are external manifestation of actions and behavior that result in harm to others. Therefore, responsibility generally means a commitment to eliminate harm to another. For legal liability fulfillment, whether civil or criminal, person must commit or leave an action that has damaged other person.

2. The correlation between appearance and perception: the correlation means companionship. This interpretation of this base is so that a benefiter must compensate damage, it is not true that one is benefiter and other is compensator. Allama Isfahani in the case of close correlation between trophy and compensation says that: "if the wasted object is owned by customer, he cannot cancel the ownership and then customer will pay inevitably the penalty, so how the seller is responsible for damage. In contrast, when we assume that buyer is owner of property before its damage, then buyer is owner and he is responsible for damage."

\section{B) Evidences of rule}

We express documents in order to prove the validity of this rule that the most important of them includes traditions (Hadith) of Prophet (pbuh) and rule of reason and induction.

1- Traditions (Hadith): The most important resource for Islamic scholars in order to prove their claims about the liability of benefits compensation includes public Hadiths that have been described in literature by Prophet. The first story is "from Ishaq ibn Ammar" who said, "to Abi Ibrahim (pbuh) that someone mortgaged his personal servant and home, then they are damaged, who is responsible? Prophet said, the owner is liable, so that compensation is awarded to the person who owns it." The story implies that a person is liable for damage that benefits from it and this is the referent (Mohammadi Ray Shahri, 1984).

Also a Hadith of Prophet (pbuh) about Mortgage shows the full text of rule, "His sheep actual fined ". Words of Prophet in this hadith and earlier hadith in terms of document and implication are the same.

2. The rational reasons: the second source of base sources on understanding this principle is "Definite reason". The title means any kind of rational operation that is done by comprehensive source in order to understand rules. On the other hand, the necessity of reason as a source is greater and more tangible in issues related to society and government compared to other sectors of Figh and law, since this method of reasoning is visible in several works of Figh.

We start our speech on rational reasons where we can consider rule "Of his sheep actual pays" as "Mahmudeh votes" according to today conditions.

What is the "Mahmudeh votes"? Mahmudeh votes with its tradition in Formal logic are described when expressing "cases matters" against "their faces". These votes are cases according to "Al- Eshart and Al- Tanbihat" book of Ibn Sina are those cases that are obtained from social education with regard to public interest, common trainings in divine regulations, morals, sensual passivity, induction of details and judgment. Khaje Nasir Aldin Tusi describes some aspects of Mahmude votes, as well as considers them as "Common goodness" or "graceful ethics". Implementing this rule is one of them (Jalil, 1998).

First- reason Sire: One reason that is studied by Mozaffar and is mentioned in "Hojjat" argument of Figh principles book is "Sire". He defines sire as: "continue people habit to do or not to do a work", then he says: "If the purpose of people includes all wise men from any race and religion, in this case, reason sire or bases are established." Implementing this rule has long been customary among all people and if we know it as sign, we have not exaggerated, since ignorant Arabs consider benefiter as responsible for the damages. It is notable that proof of this rule is "reason sire" rather than "legal Sire" (Bu Ali, 1983).

The difference between these two measures is clear concept. In reason sire, act rationally is without adherence to rituals and beliefs, but in legal sire, act is attributed to those who have commitment to Islam or specifically to Shi'a. But it may be true that the act that is attributed to reason may be attributed to law (Tabarsi, 1994). 
Second, depending on God justice: demand and search Justice is not a mere political slogan or an unattainable social ideal, but it is rooted in essence of human existence and nature and is product of pure and natural character of people; therefore, although people may act in his behavior contrary to justice and oppress others, he tends innately to justice and oppress injustice and hate. Imam Ali (AS) in its description says: "Justice Malouf and injustice Asov "justice is pleasant and oppression is deviant (Ansari, 1997).

Therefore, according to Allamah Isfahani "It is oppression that interests are for one, but the disadvantages are for another person, he takes advantage and other takes disadvantages; like people who send themselves to hell in order to prevail others!" It is contrary to justice and is oppression. So, "Of his sheep actual pays" is a rule according to ration and based on reason and spirit of justice that are mentioned in narratives (Azarnoosh, 2000).

C) Induction: in induction despite the path is from details to general unlike deduction where a general order is issued and is in line with its referents. After an investigation in ownerships, the concomitance of benefits and compensation becomes apparent and since the cases and examples are not out of limit, then induction is full, a full induction that is absolute benefit and a certainty where general order is issued (Tufa, 1950).

\section{C) Application of rule of in matters arising from law}

As mentioned the rule of "Of his sheep actual pays" is applicable in various areas of law, with all legal Figh forms, our purpose is to determine the arising issues. Therefore, the most important examples of new applications of rule are through preventing repetition (Khorasany, 1952).

1. Equitable distribution of damages: One of the new methods on this issue is equitable distribution of damage. Legal systems have long spoken about the equitable distribution of wealth and jobs and benefits so that Aristotle divides justice in distributive and exchangeable way. Exchangeable is justice that occurs spontaneously in transactions and does not require no external control however, distributive justice is used in distribution of jobs and benefits by public officials and offices (Abvzahreh, 1948).

For example, the Islamic State receives income taxes or sales tax or social and provides security insurance for poor people. Neither Aristotle and his followers nor other philosophers have not discussed on justly distribution of damages until recent years, all of them discussed on occupational, wealth and rank distribution. Opposition between benefit and harm comes to mind in Roman and Islamic law and belief in potential loss of benefit can be seen in some texts (Of his sheep actual pays). The base of equitable distribution philosophy of losses is that if social cohesion and the relationship between people in society require just division of jobs and positions, they require also, unfortunate things are divided fairly (Ibn Makki, 1976).

Sometimes the loss and damage are suffered as a result of inadequate social textures and legal, economic and facility structure of state, so that individual does not have a constructive role in that environment and everyone feels this compulsion in his conscience and understands that work failure cannot be attributed to any particular person. In this process, state obtains civil liability as a legal person. So, according to this rule, state not only is responsible for damages caused by their appliances, apparatus and staff, but also is responsible for damages or losses whose factors are not determined and is responsible to protect people against such accidents due to task of government and treasury in collecting tax and having public resources and Zakat (Jaziri, 1986).

2. The responsibility of treasury to pay the atonement: In cases such as pseudo-error murder, where murderer cannot afford to pay atonement, in error murder, or when the killer is not rational or is rational but does not have financial ability or insurance, according to our narratives, atonement pay is for Imam of Muslims and he must pay such compensation and intellectual validity confirms it because the requirement of rule (Of his sheep actual pays) is so. Who seizes the trophies, properties with no owner and property without an heir ${ }^{1}$, he must pay compensation instead of those who cannot pay. Because of Muslim blood value (Not overlooking blood Emery and Muslim), poorness of murderer or his lack, or escape, his unavailability or lack of insurance for agent or insurance lack for killer or victim do not lower its value and this is one privilege of Islamic law over international and global law (Bojnordi, 1998).

3. The government's responsibility for public health insurance: other sets of narratives that are in line with this rule (Of his sheep actual pays) are Jarire guarantee narratives. In Islam peak, as sometimes happened, a prisoner was brought from remote areas and was sold as slave and he may be released for reasons, since this person did not have

\footnotetext{
1 I asked Imam Sadiq (AS) about Anfal, he said, Anfal include: Townships that have been destroyed and its inhabitants have been gone, they are belong to God, a destroyed land that is obtained without war and struggle and all lands without owner and mines are Anfal and any person who dies without supervision, his wealth is Anfal. Ref: Vasael Shia, vol. 6, Alanfal chapters, Chapter 1, Hadith 20.
} 
any friend, collaborator, heir and family in Islamic country, he contracted with Muslim Jarire guarantee so that he is the guarantor of his crimes and if he died, he inherited his property. There are many traditions that Imam is Jarire guarantee of one who does not have a relative of mine and inherits his property and if there is a debt, imam pays (Ahmadi Abhari, 1998).

These narratives, in addition to train insurance indicate that someone who has not insured is insured by government. Finally, the narratives may show the responsibility of governments against citizens. So we can make it a priority and found that government guarantees within its territory. Many reasons have been mentioned for government, from Islam view, against any loss that people suffer, this rule is one of them (Ardabili, 2000).

4. Calculation of taxpayer tax: the rule can be used in taxes law so that tax must be paid by those who benefits from tax resources (Of his sheep actual pays). As we said, this rule opens the door to a lot of obscure questions; however, this rule faces some exceptions like other rules. Article 182 states on taxpayer: "Those in accordance with provisions of this Act are required to pay others taxes, also, anyone who has guaranteed the payment of others taxes or obligations and those who have been subject to a fine due to refuse of performing duties prescribed in this Act, they are considered as taxpayer and they will be treated in accordance with legal taxes regulations."(Delfan, 2003).

This article shows that the rule is has two exceptions:

A- People who are in charge of a task according to law and they have shown a failure to do them, according to Article (199) they are generally have executive sponsorship.

B- People who are required to pay others tax

Therefore in property tax sources, one must pay property tax that is property owner and in income taxes, one must pay tax who is earning income. However, these issues are simple and non-lawyers are aware of these basic issues, but when the simple issue is arisen as a legal issue, they fail to solve them. Suppose, for example, that an individual has given his credit card to other ones and there is economical buying for that card. Now the question is who should pay this tax?

In this case, Tax Organization knows only card and tax code holder and claims tax from him. Of course, this is defensible, but the real question is if Zeyd refers to court and according to provided documents it becomes known that there is contract between the cardholder and benefiter and accordingly benefiter has used the card and card code, in other words, benefiter uses its profits. It is noteworthy that in our opinion, the Court cannot issue the sentence of changing taxpayer name, because it is out of his authority and the disputes between taxpayer and Tax organization are solved by Court of Justice, therefore, court in such cases, will force benefiter to pay tax. However, if the case is mentioned in Board of dispute resolution, what is the responsibility of Board in this case? Specifically, the court found that there have been an agreement between these two, and it has been determined that benefiter has entitled benefits not owner. It seems that in such cases, the Board of dispute resolution must act according to rule of (Of his sheep actual pays) and according to Article 157 which says: "in cases where for any reason, the tax is claimed from other than taxpayer, after approval by Board of dispute resolution, tax claim from non- taxpayer at any stage will be void, in this case, tax organization is required to claim tax from true taxpayer during one year from issuing sentence, otherwise it will be included in time lapse". The organization must claim tax according to rule of "Of his sheep actual pays" or" Abscess security ", however Board of dispute resolution do not accept these inferences (Tavakoli, 2005).

5. The effect of rule on presumed income tax: We think that rule of (Of his sheep actual pays) is path finding in all of tax resources and it can be relied on, for example, if someone transfers property to another one, transmitter must pay "presumed income" tax according to Article 59. The reason of using word of "presumed" is that transfer is not always accompanied by revenue and profit and it seems that in this case, the legislator has determined a presumed income in order to solve the problem and for convenience and requires transmitter to pay tax. Obviously, if someone gives his property for free to other one, in this case the transmitter will not be required to pay tax. It is clear that transmitter is not achieved any benefit. In this case, the transferee is required to pay tax based on Chapter VI and Article 63 of income tax (Tabatabai, 1997).

6. The effect of rule on inheritance revenue tax: Sometimes the question is who must pay inheritance revenue tax or is it necessary to pay tax in this case. Adhering the rule of (Of his sheep actual pays) all questions can be answered. For example, a person has purchased a property and dies, the dispute is arisen after his death between heirs of buyer and seller in respect of ownership, parties refer to court, and the courts forces seller to transfer document to buys heirs, now the question is whether or not they have to pay inheritance tax?

Although, Article 37 explicitly answers this question, but in many cases, the tax organization does not receive tax due to lack of skilled lawyers and pressure of tax auditors and lack of coordination of official documents. The question may also be asked in other way there is dispute between buyer and seller, then buyer dies and the court rules in favor of purchaser's heirs (Sobhi Mahmasani, 1997). 
7. Effects of rule on general civil liability: According to this theory, the responsibility of damage factor is clear due to mere existence of causality between loss and action. In other words, the operation of any natural or legal person, without being fault or crime, makes risk and must bear the consequences. Since the advantages and benefits of work are awarded to Company, it will be responsible for losses arising from it. This view is similar to Figh rule "Of his sheep actual pays".

For example, if a company or a factory produces various products or a department is responsible for certain economic and social affairs that their income is for them, if actions and activities harm to person or persons, they will be responsible for them (Raghib Isfahani, 2001).

Apparently this theory is emerged in response to "fault theory" and in fact, it is concerned to provide justice, it accepts liability without fault and knows any detrimental action as reason for guarantee and any activity that is being beneficial are called responsible. Therefore, it is optimal approach to civil liability despite criticisms that from a group of scientists. Cases of this theory acceptance can be seen in Islamic legal texts (Mousavi Khalkhali, 1998):

- If someone invites other to his home and he enters house with the permission of owner, meanwhile the dog of owner harms him, homeowner will be guarantor.

- Individual, who rides an animal, is responsible for property that animal loses them.

- Individual who leaves an animal on people way, he will be responsible for damages that animal cause

If someone dig a well on his property and covers it, but does not acknowledge others, if someone or something fall in wall and lost or damaged, he will be responsible.

If someone pours water on his property and thereby neighbor's property is drowned or spread the fire or be aware of its harm to others, he is responsible.

If the wall is collapsed due to exhaustion who and kills human or animal or leads to financial loss, the owner of wall, in the case of knowing its exhaustion, will be responsible.

As can be seen, according to these jurisprudence sentences, the mere existence of causality between act and the harm leads to liability and this means that theory of risk in Figh is acceptable (Najafi, 1991).

8. The guarantee of seller when property is not same: Article 391 of Civil Code states as follows "If whole or part of property, seller must return its price and if the client ignores the problem with property, seller must compensate buyer damages. It can be inferred from the meaning and reason of above matter that salesperson has seized others property by conquest or it is transferred by officious sale. Therefore, according to sentence set forth in Article 314 of Civil Code, which states that "'If the confiscated property price becomes high due to violator act, violator does not right to excess part unless it is excess of same property; in this case the excess part is for violator." Article 261 of Act states: "if officious property is captured by customer, he will be responsible for property and its benefits and disadvantages over mentioned time."( Khamenei, 2002).

9. The awarded payment for delay damages: Context of this rule "Of his sheep actual pays", is that acquisition of any interest and benefit must be according to person's ability to withstand potential losses and risks. According to this rule, which form the intellectual basis of all transactions, the rights arising from transaction are equal to his commitments, however, if the owner is to be paid money at a certain time, but contracting party does not act and delays it, since he has benefited from the money or property during the delay; so he must bear the damage against this exploitation that is called compensation. There are traditions that document this rule (Zoheyly, 1986).

\section{Conclusion}

In Islamic law, "Ziman" (liability) and "Tazmin" (guarantee) words are used instead of responsibility. Ziman means the establishment of one's validity according to judge order and its main purpose is to offset losses and to establish Islamic justice and righteousness. One of cases to compensate damage and liability is personal responsibility against using and taking benefit of an object or commodity interests. The rule has long been mentioned in legal and jurisprudence trainings and is now a solution for arising issues, issues such as taxation, the state commitment and treasury in compensation and atonement, damages due to delay in payment of banks and financial institutions, etc. However it seems that legislators and analysts view to philosophy of this rule, may respond other problems (Jafarbn Hassan, 1983).

\section{References}

Abvzahreh, M., (1948). Al Shafei. Cairo: Daralfkr Arabi.

Ahmadi Abhari, M.A., (1998). Islam and social defense. Qom: Islamic Propagation Office Publication.

Ansari, M., (1997). Faraed Alosul fi tamiz Almozayyef anel alqabul [Alrasael]. Vol.24, Qom: Almotmr Alalami bemnasbah Alzekri 
Alomayeh Almilad Sheikh Al Ansar.

Ardabili, A., (2000). Zobde Albayan. Qom: believers Publication.

Azarnoosh, A., (2000). Arabic- Farsi contemporary dictionary. Tehran: Nashre Ney.

Bojnordi, M.H., (1998). Alqvad Alfqhyh. Vol. 1, Qom: Hadi Publication.

Bu Ali, S., (1983). Ilesharat Altanbihat. Vol. 1, Qom: Book Publishing Office.

Delfan, A.A., (2003). Principles of criminal responsibility in Islamic and French law. Qom: Jurisprudence and Law Institute.

Esfahani, M.H., (1994). Nhayh Aldrayh Fi sharh Alkfayh. Vol. 3, Qom: Al Beit (AS) Institute.

Fasel, H., Kashf Alsam. Vol. 2, Tehran: Farahani.

Hor Ameli, M.H., (1987). Vasayel Shia, Vol. 12, Beirut, Darahya' Altras Arabi.

Ibn Manzur, A.K., (1987). Arab language. Vol.11, Beirut: Daralahya' Altras Arabi.

Ibn Makki, A.M., (1976). [First Shahid]. Zekry Shia. Qom: Basirati Publication.

Ibn Makki, A.M., (1976). Alqvaed and Alfavaed, Vol. 1, Qom: Manshurat maktabah Almofid, [Bita].

Jaziri, A., (1986). Alfeqh Alalmazhab Alarbh. Vol.5, Beirut: Daralahya' Altras Arabi.

Jalil, GH., (1998). Islamic legal system. Qom: Global Centre for Islamic Sciences.

Jafarbn Hassan, H., (1983). Sharaye Aleslam. Vol. 1, Qom: Daralhoda Publication.

Khamenei, M., (2002). Roots and concept of justice in Islamic law and jurisprudence (Qoftequ books). Qom: Divine International Publication.

Khorasany, A., (1952). Kefayh Alosul. Vol. 2, Tehran: Islamic Publication, [Bita].

Mesbah Yazdi, M.T., (2000). Rights and policies in Qur'an, Qom: Publication of Imam Khomeini (RA) Education and Research Institute.

Mohammadi Ray Shahri, M., (1984). Mizan Alhkmh. Qom: school of Islamic boards.

Mousavi Khalkhali, M.M., (1998). Shariah and government. Qom: Islamic Propagation Office Publication.

Najafi, M.H., (1991). Javaher Alkalam Fi Sharh Sharaye Islam. Vol.42, Beirut: Arabic History Institute.

Raghib Isfahani, K., (2001). Mofradat Alalfaz Alqoran. Research by Safwan Adnan Davoodi, vol. 1, Beirut: Daralshamyh.

Sobhi Mahmasani. (1979). Legislation philosophy in Islam. Translated by Esmail Golestani, Tehran: Amir Kabir Publishing Institute.

Tabatabai, M.H., (1997). Tarjomatolmizan Fi Tafsire Alqoran. Translated by Muhammad Baqir al-Hamadani, Vol.5, Qom: Islamic Publications Office.

Tabarsi, F.I.H. (1994). Majma Albatyan Fi Tafsir al-Quran, Vol. 1, Beirut: Scientific Publication Institute.

Tavakoli, A., (2005). Interest in the Shiite and Sunni. Qom: Publication of Imam Khomeini (RA) Education and Research Institute.

Tufa, N., (1950). Almaslaha Fi Sharia Alislamiye. Risalah Islam, 2(1): 104.

Zoheyly, W., (1986). Islamic Figh principles. Vol. 1, Beirut: Daralfekr. 